\title{
A comparison between legume technologies and fallow, and their effects on maize and soil traits, in two distinct environments of the West African savannah
}

\author{
A. C. Franke · G. Laberge · B. D. Oyewole • \\ S. Schulz
}

Received: 30 August 2007/ Accepted: 6 March 2008/Published online: 22 March 2008

(C) The Author(s) 2008

\begin{abstract}
Legume-maize rotation and maize nitrogen (N)-response trials were carried out simultaneously from 1998 to 2004 in two distinct agro-ecological environments of West Africa: the humid derived savannah (Ibadan) and the drier northern Guinea savannah (Zaria). In the N-response trial, maize was grown annually receiving urea $\mathrm{N}$ at $0,30,60,90$ and $120 \mathrm{~kg} \mathrm{~N} \mathrm{ha}^{-1}$. In Ibadan, maize production increased with $\mathrm{N}$ fertilization, but mean annual grain yield declined over the course of the trial. In Zaria, no response to $\mathrm{N}$ treatments was observed initially, and an increase in the phosphorus (P) and sulphur (S) fertilizer application rate was required to increase yield across
\end{abstract}

A. C. Franke - B. D. Oyewole · S. Schulz

International Institute of Tropical Agriculture, Oyo Road, Ibadan, Nigeria

A. C. Franke $(\square)$

Department of Agrosystems Research, Plant Research International, Wageningen University and Research

Centre, P.O. Box 16, Wageningen 6700 AA,

The Netherlands

e-mail: Linus.Franke@wur.nl

G. Laberge

Department of Agricultural Sciences, Faculty of Life

Sciences, University of Copenhagen,

Højbakkegård Allé 9, Taastrup 2630, Denmark

Present Address:

S. Schulz

German Agro Action, 18th Street Sinkor, Monrovia, Liberia treatments and obtain a response to $\mathrm{N}$ applications, stressing the importance of non-N fertilizers in the savannah. In the rotation trial, a 2-year natural fallowmaize rotation was compared with maize rotated with different legume types: green manure, forage, dualpurpose, and grain legumes. The cultivation of some legume types resulted in a greater annual maize production relative to the fallow-maize combination and corresponding treatments in the N-response trial, while there was no gain in maize yield with other legume types. Large differences in the residual effects from legumes and fallow were also observed between sites, indicting a need for site-specific land management recommendations. In Ibadan, cultivation of maize after the forage legume (Stylosanthes guianensis) achieved the highest yield. The natural fallow-maize rotation had improved soil characteristics (Bray-I P, exchangeable potassium, calcium and magnesium) at the end of the trial relative to legume-maize rotations, and natural fallow resulted in higher maize yields than the green manure legume (Pueraria phaseoloides). In Zaria, maize following dual-purpose soybean achieved the highest mean yield. At both sites, variation in aboveground $\mathrm{N}$ and $\mathrm{P}$ dynamics of the legume and fallow vegetation could only partly explain the different residual effects on maize.

Keywords Aeschynomene histrix . Maize · Manure · Nitrogen · Phosphorus · Pueraria phaseoloides - Soybean (Glycine max) . Stylosanthes guianensis 


\section{Introduction}

In large parts of the Guinea savannah of West Africa, crop yields are stagnating or declining due to shortening of the fallow periods between crop cultivations and low application rates of organic inputs and chemical fertilizers (Bationo et al. 1998; De Ridder et al. 2004). Frequent cultivation of staple cereals, such as maize (Zea mays), millet (Pennisetum glaucum) and sorghum (Sorghum bicolor), has exacerbated problems of poor soil fertility and increased pest, disease and weed pressure. The inclusion of legumes in cereal-based rotations together with the appropriate use of nutrient inputs are considered to be the key to the rehabilitation and maintenance of soil fertility and productivity in intensifying cereal-based systems of the Guinea savannah (Giller 2001; Schulz et al. 2001).

Schulz et al. (2001) distinguished four types of legume technologies available for the Guinea savannah: green manure, forage, dual-purpose and grain legumes. Green manure legumes, such as Mucuna pruriens and Pueraria phaseoloides, can contribute large quantities of residual biomass and nitrogen $(\mathrm{N})$ to the soil. Some species have the potential of fixing over $200 \mathrm{~kg} \mathrm{~N}^{-1}$ (Sanginga et al. 1996a, b; Muhr et al. 1999a). The adoption of green manure technologies by farmers has remained limited, despite considerable efforts to promote them among farmers and evidence of their beneficial effects on soil fertility and cereal yields (Muhr et al. 1999b, 2002; Carsky et al. 2001). This is likely related to a general reluctance of farmers to invest land, labour and seed in a technology that does not provide a quick economic return on investments (Schulz et al. 2001). Forage legume species, such as Stylosanthes spp., can produce biomass yields of up to $20 \mathrm{t} \mathrm{ha}^{-1}$ year $^{-1}$ in the savannah and provide high-quality animal feed (Tarawali 1994; Muhr et al. 1999a). They can also contribute to soil fertility by providing carbon and nutrient inputs in the form of plant residues remaining in the field after harvest and as animal manure produced from the harvested forage (Mohamed Saleem and Otsyina 1986; Tarawali and Peters 1996). The adoption of forage legumes in West Africa has been low among farmers, partially because of the aim of most livestock farmers is to achieve an acceptable survival rate of livestock over the dry season rather than maximum productivity (Thomas and Sumberg 1995; Sumberg 2002). Grain legumes are bred to produce high yields of edible grains rather than a high $\mathrm{N}$ fixation or leafy biomass production. Therefore, their benefits in terms of soil fertility are generally less than those from green manure or forage legumes (Schulz et al. 2001; Sanginga 2003). Nevertheless, roots, rhizodeposits and aboveground residues left after harvest contribute to soil organic $\mathrm{C}$ and $\mathrm{N}$ reserves. Dual-purpose (DP) legumes combine an acceptable production of leafy material, which can be used as animal feed, with the production of edible grains. Their harvest index is generally below that of grain legume varieties. Grain and DP legumes have the advantage of giving a rapid return to investments in the form of edible grains. Traditional and improved grain and DP varieties of groundnut (Arachis hypogaea), soybean (Glycine max) and cowpea (Vigna unguiculata) have been widely adopted throughout the savannah (Sanginga et al. 2003). Published evidence suggests that benefits derived from legume technologies and fallow to improve cereal yields and soil fertility in the savannah are ranked in the following order: green manure legume $>$ forage legume $>$ DP legume $>$ grain legume $>$ natural fallow (Schulz et al. 2001).

Increases in the yield of cereal crops following the cultivation of legumes relative to those obtained with continuous cereal cropping have been frequently reported in the Guinea savannah (Muhr et al. 1999b; Alvey et al. 2001; Franke et al. 2004; Fofana et al. 2005). Often the amount of $\mathrm{N}$ and sometimes phosphorus $(\mathrm{P})$ available to cereals improves in legume-cereal rotations. Other soil chemical properties, such as $\mathrm{pH}$, may also be favourably affected by the cultivation of legumes (Alvey et al. 2001; Sanginga 2003; Tian ?tul?> et al. 2005). Rotations may affect soil microbial populations, arbuscular mycorrhizae and parasitic nematode populations (Bagayoko et al. 2000; Alvey et al. 2001, 2003; Marschner et al. 2004). However, it remains difficult to quantify to what extent changes in soil biota relate to variations in cereal yield. Legumes in cereal-based rotations can also reduce weed pressure; for example, that of the obnoxious weed Striga hermonthica (Carsky et al. 2000; Franke et al. 2006).

Few medium- and long-term studies of the performance of legume-cereal rotations have been conducted in West Africa (Swift et al. 1994; Juo et al. 1995; Tian et al. 2005). There is also little information from multi-site trials comparing the performance of legume-cereal rotations (Buerkert 
et al. 2002; Fofana et al. 2005). Such information is important for targeting legume technologies appropriate to different biophysical and socio-economic environments, which in turn enhances the likelihood that such technologies will be adopted by farmers. The trials reported here were conducted simultaneously over a period of 7 years (1998-2004) in two distinct environments of the savannah: the relatively humid derived savannah and the drier northern Guinea savannah. The objectives of the trials were to evaluate the biomass, $\mathrm{N}$ and $\mathrm{P}$ dynamics, and yield in various legume technologies and a natural fallow rotated with maize and to compare these parameters with those obtained in continuous maize rotations receiving different amounts of $\mathrm{N}$ fertilizer. The effects of rotations on soil chemical properties were also analysed, and the relative benefits from different legume technologies and fallow with respect to improvements in soil fertility and subsequent cereal yield were examined.

\section{Materials and methods}

Experimental sites

Maize N-response trials and legume-maize rotation trials were conducted simultaneously in two environments of the Guinea savannah in Nigeria from 1998 to 2004. In the N-response trial, maize was grown annually at both locations receiving urea $\mathrm{N}$ at a rate of $0,30,60,90$ or $120 \mathrm{~kg} \mathrm{~N} \mathrm{ha}^{-1}$. The rotation trials were established adjacent to the $\mathrm{N}$-response trials. A 2-year natural fallow-maize rotation was compared with maize rotated with different legume types: green manure, forage, DP and grain legumes. One site was located on the campus of the International Institute of Tropical Agriculture (IITA), Ibadan, southwest Nigeria, in the derived savannah zone $\left(7^{\circ} 30^{\prime} \mathrm{N}, 3^{\circ} 54^{\prime} \mathrm{E}\right.$, $213 \mathrm{~m}$ a.s.1.). This site has a bi-modal rainfall pattern peaking in June and October with a long-term mean annual rainfall of $1290 \mathrm{~mm}$ and a growing period of 210-270 days. Outside of the growing period, it rains only occasionally. The soil type is a Plinthic Luvisol (FAO 1988). Prior to the trial, the site was cropped with cereals between 1989 and 1994 and was under natural fallow from 1995 to 1997 . The other site was located at the experimental Shika farm of Ahmadu Bello University/Institute for Agricultural Research in Zaria, Nigeria, in the northern Guinea savannah eco-zone $\left(10^{\circ} 24^{\prime} \mathrm{N}, 7^{\circ} 42^{\prime} \mathrm{E}, 680 \mathrm{~m}\right.$ a.s.1.). This site has a mono-modal rainfall distribution, an annual mean rainfall of $1050 \mathrm{~mm}$ and a growing season of 120-150 days. Rain outside the growing season is rare. The soil type is a Haplic Lixisol (FAO 1988). The trial site was cropped with cereals from 1985 to 1994 with no or very small additions of chemical fertilizer and organic inputs and was under natural fallow from 1995 to 1997 . Prior to trial establishment, the fallow vegetation at both sites was cut and burned. The trial sites were then disc-harrowed twice and ridged by tractor. All subsequent management operations were done manually. Rainfall was recorded daily at both sites.

\section{$\mathrm{N}$-response trial}

The N-response trial was set up as a randomized complete block design (RCBD) with each block containing a full set of treatments and four repetitions at each location. Maize was cultivated annually from 1998 to 2004 on the plots $(4.5 \times 6 \mathrm{~m})$. The treatments consisted of urea $\mathrm{N}$ applied at rates of $0,30,60,90$ or $120 \mathrm{~kg} \mathrm{~N} \mathrm{ha}^{-1}$. Phosphorus and potassium (K) were applied to all plots annually at rates of $17 \mathrm{~kg} \mathrm{P} \mathrm{ha}^{-1}$ as Triple Super Phosphate (TSP) and $33 \mathrm{~kg} \mathrm{~K} \mathrm{ha}^{-1}$ as Muriate of Potash (Table 1). In Zaria, poor responses to increasing $\mathrm{N}$ rates were observed in 1998-2001. A pot trial indicated that, in addition to a $\mathrm{N}$ deficiency, maize growth was limited by deficiencies of $\mathrm{P}$ and sulphur (S) (Schulz et al. 2002). Therefore, from 2002, $\mathrm{P}$ applications in Zaria were increased to $40 \mathrm{~kg} \mathrm{P} \mathrm{ha}^{-1}$, of which $20 \mathrm{~kg} \mathrm{P}$ was applied as TSP and $20 \mathrm{~kg} \mathrm{P}$ as Single Super Phosphate (SSP); SSP also added $28 \mathrm{~kg} \mathrm{~S} \mathrm{ha}^{-1}$ (Table 1).

Prior to planting, weeds and residual biomass were cut and incorporated into the soil during ploughing (Ibadan) or ridging (Zaria). The maize varieties were TZL Comp. 4 (Ibadan) and TZL Comp. 1 (Zaria). Both are open-pollinated, long-duration varieties recommended for the respective local biophysical environments. Following common practices, maize was grown on ridges in Zaria and on flat land following land preparation in Ibadan. Planting was done at 0.75-m row spacing with an intra-row distance of $0.25 \mathrm{~m}$ (approx. 53,333 plants $\mathrm{ha}^{-1}$ ). Depending on weather conditions, the exact planting and harvesting dates varied among years and locations (Table 2). Gap 
Table 1 Annual application rates of $\mathrm{N}, \mathrm{P}, \mathrm{K}$ and $\mathrm{S}\left(\mathrm{kg} \mathrm{ha}^{-1}\right)$ in chemical fertilizer in the N-response and rotation trials

\begin{tabular}{|c|c|c|c|c|c|c|c|c|c|c|c|c|c|c|c|c|}
\hline \multirow[t]{3}{*}{ Year } & \multicolumn{8}{|c|}{ N-response trial } & \multicolumn{8}{|c|}{ Rotation trial } \\
\hline & \multicolumn{4}{|l|}{ Ibadan } & \multicolumn{4}{|l|}{ Zaria } & \multicolumn{4}{|c|}{ Ibadan } & \multicolumn{4}{|c|}{ Zaria } \\
\hline & $\mathrm{N}$ & $\mathrm{P}$ & $\mathrm{K}$ & $\mathrm{S}$ & $\mathrm{N}$ & $\mathrm{P}$ & $\mathrm{K}$ & $\mathrm{S}$ & $\mathrm{N}$ & $\mathrm{P}$ & $\mathrm{K}$ & $\mathrm{S}$ & $\mathrm{N}$ & $\mathrm{P}$ & $\mathrm{K}$ & S \\
\hline 1998 & $0-120$ & 17 & 33 & 0 & $0-120$ & 17 & 33 & 0 & 0 & 17 & 33 & 0 & 0 & 17 & 33 & 0 \\
\hline 1999 & $0-120$ & 17 & 33 & 0 & $0-120$ & 17 & 33 & 0 & 0 & 17 & 33 & 0 & 0 & 17 & 33 & 0 \\
\hline 2000 & $0-120$ & 17 & 33 & 0 & $0-120$ & 17 & 33 & 0 & $0 / 30$ & 17 & 33 & 0 & $0 / 30$ & 17 & 33 & 0 \\
\hline 2001 & $0-120$ & 17 & 33 & 0 & $0-120$ & 17 & 33 & 0 & 0 & 17 & 33 & 0 & 0 & 17 & 33 & 0 \\
\hline 2002 & $0-120$ & 17 & 33 & 0 & $0-120$ & 40 & 33 & 28 & $0 / 60$ & 17 & 33 & 0 & $0 / 60$ & 40 & 33 & 28 \\
\hline 2003 & $0-120$ & 17 & 33 & 0 & $0-120$ & 40 & 33 & 28 & 0 & 17 & 33 & 0 & 0 & 40 & 33 & 28 \\
\hline 2004 & $0-120$ & 17 & 33 & 0 & $0-120$ & 40 & 33 & 28 & $0 / 60$ & 17 & 33 & 0 & $0 / 60$ & 40 & 33 & 28 \\
\hline
\end{tabular}

Table 2 Growing periods of maize, legumes and fallow in the N-response and rotation trial (number of Julian days from planting to harvest)

\begin{tabular}{|c|c|c|c|c|c|c|c|}
\hline Site/crop & 1998 & 1999 & 2000 & 2001 & 2002 & 2003 & 2004 \\
\hline \multicolumn{8}{|l|}{ Ibadan } \\
\hline Maize & $129-258$ & $146-252$ & $117-241$ & $138-255$ & $137-246$ & $127-248$ & $133-256$ \\
\hline Fallow $^{\mathrm{a}}$ & $258-\ldots$ & $\ldots$ & $\ldots 108 \mid 241-\ldots$ & $\ldots$ & $\ldots 129$ | $246-\ldots$ & $\ldots$ & $\ldots 122 \mid 256-\ldots$ \\
\hline Pueraria phaseoloides ${ }^{\mathrm{a}}$ & $169-\ldots$ & $\ldots$ & $\ldots 108 \mid 185-\ldots$ & $\ldots$ & $\ldots 129 \mid 151-\ldots$ & $\ldots$ & $\ldots 122 \mid 179-\ldots$ \\
\hline Stylosanthes guianensis & $169-\ldots$ & $\ldots 335$ & $185-\ldots$ & $\ldots 331$ & $151-\ldots$ & $\ldots 324$ & $179-\ldots$ \\
\hline DP soybean & & $144-278$ & & $144-281$ & & $133-276$ & \\
\hline Grain cowpea & & $124-214$ & & $136-198$ & & $112-171$ & \\
\hline Grain soybean & & $217-319$ & & $215-312$ & & $185-318$ & \\
\hline \multicolumn{8}{|l|}{ Zaria } \\
\hline Maize & $158-269$ & $172-271$ & $166-284$ & $154-261$ & $158-260$ & $176-301$ & $153-282$ \\
\hline Fallow $^{\mathrm{a}}$ & $269-\ldots$ & $\ldots$ & $\ldots 156 \mid 284-\ldots$ & $\ldots$ & $\ldots 151 \mid 260-\ldots$ & $\ldots$ & $\ldots 142 \mid 282-\ldots$ \\
\hline Aeschynomene histrix ${ }^{\mathrm{a}}$ & $211-\ldots$ & $\ldots$ & $\ldots 156 \mid 212-\ldots$ & $\ldots$ & $\ldots 151 \mid 213-\ldots$ & $\ldots$ & $\ldots 142 \mid 181-\ldots$ \\
\hline S. guianensis & $211-\ldots$ & $\ldots 321$ & $212-\ldots$ & $\ldots 314$ & $213-\ldots$ & $\ldots 318$ & $181-\ldots$ \\
\hline DP soybean & & $154-293$ & & $152-300$ & & $148-316$ & \\
\hline Grain cowpea & & $145-232$ & & $152-212$ & & $148-223$ & \\
\hline Grain soybean & & $233-314$ & & $213-313$ & & $223-316$ & \\
\hline
\end{tabular}

DP, Dual purpose

${ }^{a}$ Biomass production of fallow and green manure legumes was measured at the time of S. guianensis harvest; thereafter, the vegetation was left undisturbed until preparations for maize planting in the following year

filling in maize stands was done 10 days after planting; hoe-weeding was done in the second and fifth week after planting (WAP). All fertilizers were broadcast before land preparation, except for urea $\mathrm{N}$, which was spot-applied-50\% after the first weeding and 50\% after the second weeding. During harvest, all aboveground maize parts were removed from the plots.

Yield was determined from the four centre rows, each $5 \mathrm{~m}$ long, discarding $0.5 \mathrm{~m}$ at both ends of the plot. Cobs were removed from the harvested plants and shelled, and the total fresh weight of stalks, empty spindles and grain was measured. Dry matter content was determined from representative subsamples of grain, stalks and empty spindles. These were weighed, dried in a forced-air oven at $60^{\circ} \mathrm{C}$ for $72 \mathrm{~h}$ and reweighed. The combined dry matter of stalks and empty spindles will be referred to as 'maize stover' hereafter. 
Rotation trial

\section{Rotation trial: layout, treatments and agronomic practices}

The experimental layout of the rotation trial was a RCBD with a split-plot design and four replications at each site. The main-plot treatments $(9 \times 6 \mathrm{~m})$ were 2-year rotations. Natural fallow, green manure legumes, forage legumes, long-duration DP legumes and short-duration grain legumes were rotated with maize (Table 3). Legume species and varieties were selected on the basis of previously conducted screening trials (Muhr et al. 1999a; Tarawali 1994). As green manure legume, Pueraria phaseoloides was grown in Ibadan and Aeschynomene histrix in Zaria. As forage legume, Stylosanthes guianensis was grown at both locations. As DP legume, a long-duration soybean cultivar (TGx-1864, approx. 120 days) was chosen, while the grain legume treatment involved sequential double cropping of short-duration cowpea (var. IT-90K-284-2, approx. 60 days), followed by short-duration soybean (TGx-1485-1 D, approx. 85 days), both grown in a single season.

The natural fallow established itself after maize harvest and was left undisturbed until subsequent maize planting, approximately 18 months later (Table 2). Green manure legumes and S. guianensis were relayed into maize 8 weeks after maize planting (Table 2). After maize harvest, the young legume plants tolerated the dry season and continued growing in the following rainy season. Green manure legumes remained in the field undisturbed until land preparations for subsequent maize planting had been carried out. Stylosanthes guianensis foliage was harvested at the end of the rainy season. The DP soybean and grain legumes were planted during the rainy season of 1999, 2001 and 2003 and harvested when fully mature. Grain soybean was planted directly after grain cowpea harvest.

Legumes and fallow did not receive any $\mathrm{N}$ fertilizer, while $\mathrm{P}$ and $\mathrm{K}$ application rates were similar to those in the maize trial (i.e. $17 \mathrm{~kg} \mathrm{P} \mathrm{ha}^{-1}$ and $33 \mathrm{~kg} \mathrm{~K} \mathrm{ha}^{-1}$, increased to $40 \mathrm{~kg} \mathrm{P} \mathrm{ha}^{-1}$ and $28 \mathrm{~kg} \mathrm{~S} \mathrm{ha}^{-1}$ in Zaria in 2003) (Table 1). The fertilizer provided in the fallow and legumes was broadcast at the beginning of the rainy season in 1999, 2001 and 2003. Seeds of green manure legumes and S. guianensis were planted between the maize rows at a rate of 8-10 kg seed ha ${ }^{-1}$. Stylosanthes guianensis and A. histrix seeds were scarified prior to planting using a hot water treatment (Tarawali et al. 1995). The DP soybean and grain legumes were planted on flat land in Ibadan and on ridges in Zaria at a row distance of $0.50 \mathrm{~m}$ and an intra-row distance of $0.15 \mathrm{~m}$.

Field management in the rotation trial in years when maize was grown (1998, 2000, 2002 and 2004) was similar to that in the N-response trial, using the same varieties, crop management, and planting and harvest dates (Table 2). Urea $\mathrm{N}$ application rates, however, were different (Table 1). In 1998, the establishment year, maize was grown without $\mathrm{N}$ application. From 2000, main plots were split in two subplots $(4.5 \times 6 \mathrm{~m})$ that received urea $\mathrm{N}$ or not. In 2000, urea $\mathrm{N}$ was applied in subplots at 0 or $30 \mathrm{~kg} \mathrm{~N} \mathrm{ha}^{-1}$; in 2002 and 2004, the rate applied in subplots was increased to $60 \mathrm{~kg} \mathrm{~N}^{-1}$ to enhance the $\mathrm{N}$ treatment effects. The application rates and methodology used for $\mathrm{P}$ and $\mathrm{K}$ were similar to those in the N-response trial. As in the N-response trial,

Table 3 Annual cropping pattern in the rotation trial

\begin{tabular}{lll}
\hline Rotation & $1999,2001,2003$ & $1998,2000,2002,2004$ \\
\hline Fallow-maize & Natural fallow & Maize $(0 \mathrm{~N} /+\mathrm{N})^{\mathrm{c}}$ \\
Green manure legume-maize & $P .{\text { phaseoloides } / \text { A. } \text { histrix }^{\mathrm{b}}}^{\mathrm{c}}$ & Maize $(0 \mathrm{~N} /+\mathrm{N})^{\mathrm{c}}$ \\
Forage legume-maize & $S$. guianensis $^{\mathrm{c}}$ & Maize $(0 \mathrm{~N} /+\mathrm{N})^{\mathrm{c}}$ \\
DP legume-maize & DP soybean & Maize $(0 \mathrm{~N} /+\mathrm{N})^{\mathrm{c}}$ \\
Grain legumes-maize & Grain cowpea-Grain soybean & Maize $(0 \mathrm{~N} /+\mathrm{N})^{\mathrm{c}}$ \\
\hline
\end{tabular}

Fallow, green manure legumes and $S$. guianensis were established during or after maize cultivation in the preceding year

a In Ibadan

b In Zaria

c $+\mathrm{N}$ represents $30 \mathrm{~kg} \mathrm{~N}^{-1}$ in 2000 and $60 \mathrm{~kg} \mathrm{~N} \mathrm{ha}^{-1}$ in 2002 and 2004; no urea $\mathrm{N}$ was applied in 1998 
$\mathrm{P}$ and $\mathrm{S}$ application rates in Zaria were increased to $40 \mathrm{~kg} \mathrm{P} \mathrm{ha}^{-1}$ and $28 \mathrm{~kg} \mathrm{~S}^{-1}$ from 2002 (Table 1).

\section{Rotation trial: harvest procedures}

The yield of maize grain and stover in the rotation trial was determined at maturity in each subplot in a similar way as in the N-response trial. Aboveground biomass production of the natural fallow, green manure legume and S. guianensis was measured at the end of the rainy season in 1999, 2001 and 2003. Biomass yield was measured in two $1-\mathrm{m}^{2}$ quadrats in each subplot. Total fresh biomass was weighed, and dry matter content was determined from sub-samples that were dried in a forced air oven at $60^{\circ} \mathrm{C}$ for $72 \mathrm{~h}$. The remaining fresh biomass of the natural fallow and the green manure legume was returned to the plots. Grain and foliage production in DP soybean and grain legumes was assessed at crop maturity. Total fresh grain and foliage yield was measured in each subplot from four 5-m-long centre rows, discarding $0.5 \mathrm{~m}$ at both ends of the row. Dry matter content was determined from representative subsamples. In 2004, prior to preparing the land for maize planting, total aboveground biomass was measured in two $1-\mathrm{m}^{2}$ quadrats in each subplot, and dry weight was determined from sub-samples. Species composition of the natural fallow vegetation was monitored at the end of the dry season before maize planting.

\section{Rotation trial: foliage and manure handling}

Foliage produced by S. guianensis and DP soybean, including empty soybean pods, was bulked for each location at harvest. This foliage was fed over the subsequent dry season to N'Dama steers, kept in pens with concrete floors in Ibadan. The animals were conditioned with similar feed for 1 week prior to being fed with the experimental fodder. Pens were cleaned daily, and feed leftovers were mixed with faeces and urine. The manure was stored in bags under a roof for 2-3 months, until the onset of the subsequent cropping season. The manure was then applied to the respective plots in quantities corresponding to the foliage biomass produced in each plot. In Ibadan, manure was spread over the surface and incorporated into the soil during ploughing. In Zaria, manure was applied in the furrows of the old ridges and incorporated when new ridges were made. In other treatments (fallow, green manure and grain legumes), all foliage remained in the field after harvest. Plant biomass was incorporated into the soil during ploughing or ridging prior to maize planting. To facilitate its incorporation, plant biomass was sometimes partially burned, primarily to reduce the biomass of the natural fallow vegetation.

\section{Rotation trial: plant and soil analyses}

Total $\mathrm{N}$ and $\mathrm{P}$ concentrations in plant samples (maize grain and stover from 2004 combined, fallow biomass and legume foliage and edible grains sampled in 2003, weeds and legume residues sampled prior to maize planting in 2004), were determined using hot acid digestion (Novozamsky et al. 1983) followed by colorimetric analysis (Murphy and Rilly 1962; Searle 1984). The N and P concentrations in foliage that served as cattle feed and those of manure applied in the field were measured in seasons when manure was produced using the same analytical methods. Initial soil conditions (depth $0-0.15 \mathrm{~m}$ ) were assessed at both sites in 1998 (Schulz et al. 2002). In 2005, before the start of planting operations, soil samples (depth $0-0.12 \mathrm{~m}$ and 0.12 $0.24 \mathrm{~m}$ ) were taken in the rotation trial using a soil auger $22.5 \mathrm{~mm}$ in diameter. In each subplot, 12 samples were combined to one composite sample for analyses. $\mathrm{pH}\left(\mathrm{H}_{2} \mathrm{O}, 1: 1\right.$ soil to $\mathrm{H}_{2} \mathrm{O}$ ratio), organic $\mathrm{C}$ (Walkley-Black method), total $\mathrm{N}$ (macro-Kjeldahl method), Bray-I available $\mathrm{P}$ and exchangeable $\mathrm{K}$, calcium $(\mathrm{Ca})$ and magnesium $(\mathrm{Mg})$ were analysed by IITA's analytical services lab (IITA 1981).

\section{Data handling}

Maize and legume yield, plant $\mathrm{N}$ and $\mathrm{P}$ concentration and content, and soil parameters were statistically analysed year-by-year using the mixed model procedure (Litell et al. 1996; SAS Institute 1999). Since biophysical conditions and varieties differed between sites, results from each site were analysed separately. In the $\mathrm{N}$-response trial, $\mathrm{N}$ application was treated as a fixed effect and replicate as a random effect. Longterm trends in the $\mathrm{N}$-response trial were analysed using the repeated-measurements procedure (Litell et al. 1996). In the rotation trial, fixed effects of the mixed model were $\mathrm{N}$ application nested within 
rotation, and replicate was a random effect. As treatments in the rotation trial represented different legume crops and a fallow, only differences between $\mathrm{N}$ levels were statistically tested in parameters associated with legumes and fallow. These were insignificant and, therefore, legume and fallow data are presented as the mean of both $\mathrm{N}$ levels (Fig 2; Tables 6 and 7). Similarly, analyses of soil characteristics showed no differences between $\mathrm{N}$ application rates and are therefore presented as the mean of both $\mathrm{N}$ levels (Table 10). Variation between treatments was considered to be significant at a confidence level of $P<0.05$. Variability of the means is given as the standard error of the means (SE), presented as $y$-error bars in Fig 2. Soil nutrient and $\mathrm{C}$ concentrations from the 2005 samples were converted to a soil mass basis with a soil reference mass of $2200 \mathrm{t} \mathrm{ha}^{-1}$, representing a soil layer approximately $0.16 \mathrm{~m}$ thick (Ellert and Bettany 1995). Maize and legume grain yield was converted to $12 \%$ moisture.

\section{Results}

Rainfall

Total rainfall in Ibadan was well below average in 1998 (Fig. 1a). The seasons in 2003 and 2004 also differed from average with abnormal dry periods in the middle of the growing season. In Zaria, total rainfall was well below average in 1999, while in 1998 the rains came late, causing a drought period directly after maize planting (Fig. 1b). Rainfall conditions are referred to later in this paper in discussing differences in crop performance.

\section{$\mathrm{N}$-response trial}

In Ibadan, maize grain yield in the N-response trial showed a significant, positive response to increasing $\mathrm{N}$ rates in 1998-2002, but not in 2003-2004 (Table 4). Repeated measurement analyses revealed significant changes in mean grain yield and in response to $\mathrm{N}$ applications over the years. Mean annual grain yield in Ibadan was $4.0 \mathrm{Mg} \mathrm{ha}^{-1}$ in 1998. Yields then stagnated around $3.5 \mathrm{Mg} \mathrm{ha}^{-1}$ from 1999 to 2002 and further decreased to 3.0 and $2.6 \mathrm{Mg} \mathrm{ha}^{-1}$ in 2003 and 2004, respectively. At $0 \mathrm{~N}$, grain yield was highest in the first year of the
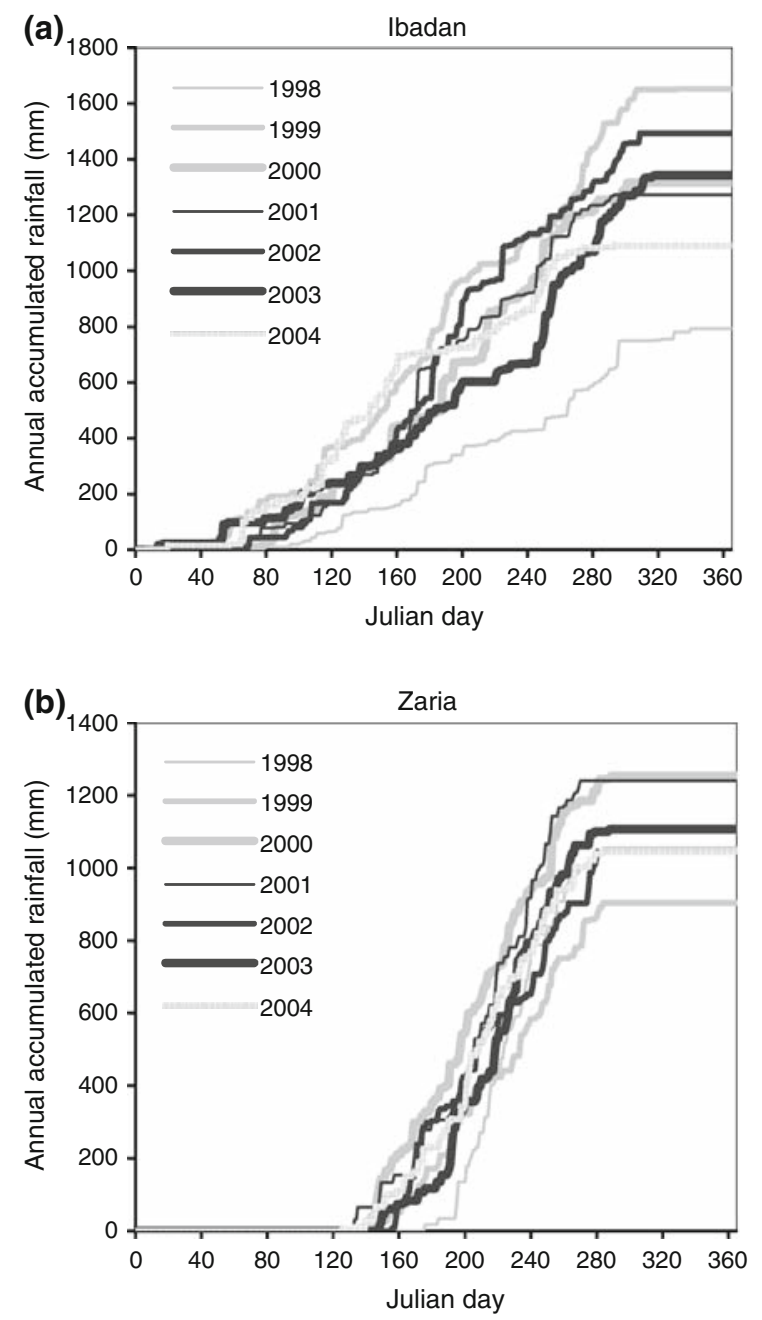

Fig. 1 Daily accumulated rainfall in Ibadan (a) and Zaria (b)

experiment (3.2 $\mathrm{Mg} \mathrm{ha}^{-1}$ ) and remained above 2.0 $\mathrm{Mg} \mathrm{ha}^{-1}$ afterwards. Thus, the soil could sustain modest maize yields without $\mathrm{N}$ applications for 7 years. Maize yield response to fertilizer applications remained relatively steady in 1999-2002. The responses to fertilizer application decreased in 2003 and 2004. This decrease in yield response was either related to a decreasing capacity of the soil make applied $\mathrm{N}$ available for plant uptake or to factors other than $\mathrm{N}$ availability that limited maize yield. In Zaria, from 1998 to 2001, grain yield was not affected by $\mathrm{N}$ application (Table 4). After an increase in the $\mathrm{P}$ and $\mathrm{S}$ application rates, average grain yield across treatments increased from $1.7 \mathrm{Mg} \mathrm{ha}^{-1}$ in 1998-2001 to 2.7 $\mathrm{Mg} \mathrm{ha}^{-1}$ in 2002-2004. The response of maize grain yield to $\mathrm{N}$ applications became significant in 
Table 4 Maize grain yield in the N-response trial $\left(\mathrm{Mg} \mathrm{ha}^{-1}\right)$

\begin{tabular}{lllllllll}
\hline Site & $\mathrm{N}$ rate & 1998 & 1999 & 2000 & 2001 & 2002 & 2003 & 2004 \\
\hline Ibadan & $0 \mathrm{~N}$ & 3.2 & 1.9 & 1.8 & 2.1 & 2.6 & 2.5 & 2.1 \\
& $30 \mathrm{~N}$ & 4.0 & 3.1 & 3.4 & 3.0 & 2.7 & 3.1 & 2.3 \\
& $60 \mathrm{~N}$ & 4.2 & 3.5 & 3.9 & 3.9 & 3.0 & 2.4 & 2.5 \\
& $90 \mathrm{~N}$ & 4.4 & 4.4 & 4.0 & 4.4 & 4.0 & 3.2 & 2.9 \\
& $120 \mathrm{~N}$ & 4.1 & 4.4 & 4.4 & 4.6 & 4.6 & 3.6 & 3.2 \\
& Mean & 4.0 & 3.5 & 3.5 & 3.6 & 3.4 & 3.0 & 2.6 \\
& Standard error & 0.25 & 0.27 & 0.30 & 0.278 & 0.38 & 0.444 & 0.24 \\
& $0 \mathrm{~N}$ & 1.2 & 1.0 & 1.2 & 1.9 & 2.1 & 1.2 & 1.6 \\
& $30 \mathrm{~N}$ & 0.8 & 1.5 & 1.2 & 2.2 & 2.6 & 2.2 & 1.9 \\
& $60 \mathrm{~N}$ & 1.6 & 1.3 & 1.7 & 2.9 & 3.6 & 2.7 & 2.5 \\
& $90 \mathrm{~N}$ & 1.8 & 1.4 & 2.2 & 2.7 & 4.0 & 3.7 & 3.3 \\
& $120 \mathrm{~N}$ & 1.6 & 1.3 & 1.8 & 2.6 & 4.9 & 4.4 & 3.9 \\
& Mean & 1.4 & 1.3 & 1.6 & 2.4 & 3.4 & 2.8 & 2.6 \\
& Standard error & 0.61 & 0.39 & 0.49 & 0.42 & 0.28 & 0.47 & 0.47 \\
\hline
\end{tabular}

Table 5 Maize grain yield in the rotation trial $\left(\mathrm{Mg} \mathrm{ha}^{-1}\right)$ and the average yield increase in treatments of the rotation trial with the same fertilizer treatments as those in the N-response trial and in the same years

\begin{tabular}{|c|c|c|c|c|c|c|c|c|}
\hline \multirow[t]{2}{*}{ Rotation } & \multicolumn{2}{|l|}{2000} & \multicolumn{2}{|l|}{2002} & \multicolumn{2}{|l|}{2004} & \multicolumn{2}{|c|}{ Percentage in increase over N-response } \\
\hline & $0 \mathrm{~N}$ & $30 \mathrm{~N}$ & $0 \mathrm{~N}$ & $60 \mathrm{~N}$ & $0 \mathrm{~N}$ & $60 \mathrm{~N}$ & $0 \mathrm{~N}$ & $+\mathrm{N}$ \\
\hline \multicolumn{9}{|l|}{ Ibadan } \\
\hline Fallow-maize & 3.7 & 4.9 & 2.9 & 4.3 & 2.9 & 4.3 & 44 & 50 \\
\hline P. phaseoloides-maize & 5.2 & 5.3 & 2.3 & 3.8 & 2.3 & 3.4 & 50 & 39 \\
\hline S. guianensis-maize & 4.8 & 5.3 & 3.2 & 4.3 & 4.0 & 4.8 & 81 & 61 \\
\hline DP soybean-maize & 2.6 & 3.6 & 2.0 & 2.9 & 1.7 & 3.0 & -4 & 7 \\
\hline Grain legumes-maize & 2.7 & 3.4 & 2.1 & 3.5 & 2.2 & 3.2 & 7 & 14 \\
\hline Standard error & 0.32 & 0.35 & 0.29 & 0.36 & 0.21 & 0.26 & & \\
\hline \multicolumn{9}{|l|}{ Zaria } \\
\hline Fallow - maize & 1.1 & 1.4 & 1.6 & 2.5 & 1.0 & 2.9 & -23 & -6 \\
\hline A. histrix - maize & 1.1 & 1.6 & 2.2 & 4.1 & 3.6 & 4.1 & 44 & 33 \\
\hline S. guianensis - maize & 1.5 & 1.5 & 3.0 & 3.3 & 4.8 & 4.3 & 91 & 25 \\
\hline DP soybean-maize & 2.9 & 2.8 & 3.7 & 4.3 & 4.3 & 4.6 & 127 & 59 \\
\hline Grain legumes-maize & 2.0 & 2.4 & 3.3 & 3.9 & 2.8 & 4.0 & 69 & 41 \\
\hline Standard error & 0.48 & 0.44 & 0.23 & 0.45 & 0.27 & 0.42 & & \\
\hline
\end{tabular}

2002-2004. However, mean annual grain yields and yield response to $\mathrm{N}$ treatments declined in 2002-2004.

\section{Rotation trial}

\section{Rotation trial: maize grain yield}

In 1998, when maize in the rotation trial was grown without urea-N, mean grain yield was 3.6 (SE 0.24$) \mathrm{Mg} \mathrm{ha}^{-1}$ in Ibadan and 0.85
(SE 0.307) $\mathrm{Mg} \mathrm{ha}^{-1}$ in Zaria (data not shown). In 2000-2004, maize grain yield in Ibadan was significantly affected by rotation and $\mathrm{N}$ rate (Table 5). Across years, the highest yield in Ibadan was achieved by maize following $S$. guianensis (forage legume) cultivation. In particular, at $0 \mathrm{~N}$ at the end of the trial (2004), the yield difference between maize after $S$. guianensis and maize in other rotations was large, which suggests that $S$. guianensis was more effective in enhancing soil fertility over the course of 
the trial than the other rotations. Maize yield after $P$. phaseoloides (green manure legume) cultivation was fairly high in 2000, but decreased in 2002-2004. In these latter years, maize after fallow achieved greater yields than maize after $P$. phaseoloides cultivation. Maize yields were lower following the cultivation of DP soybean and grain legumes. In comparison with the same treatments in the $\mathrm{N}$-response trial, the cultivation of DP soybean or grain legumes did not result in an increase in maize yield, while large gains were achieved by maize after $P$. phaseoloides, fallow and S. guianensis (Table 5).

In Zaria, maize grain yield was significantly affected by rotation in 2000-2004 and by $\mathrm{N}$ level in 2002-2004 (Table 5). As in the N-response trial, the increase in $\mathrm{P}$ and $\mathrm{S}$ fertilization rate from 2002 had a strong impact on yield and the response to urea-N. Maize cultivation after DP soybean enrichment achieved the highest mean grain yield across $\mathrm{N}$ levels, with an outstanding yield in 2000. Maize yield steadily increased over the course of the trial in the DP soybean and A. histrix treatments and more strongly in the $S$. guianensis treatment. This is probably due to the increase in $\mathrm{P}$ and $\mathrm{S}$ fertilization rates and treatment effects. In plots receiving urea-N, differences in grain yield between the legume-maize rotations were smaller than those in the $0 \mathrm{~N}$ treatments in 2002 and 2004, possibly because additional urea- $\mathrm{N}$ applications may have masked differences in soil $\mathrm{N}$ supply between rotations. Maize yield after fallow was below that of maize after legume cultivation and also below that of the treatments in the $\mathrm{N}$-response trial at the same $\mathrm{N}$ rates. Grain yields in the legume-maize rotations were all higher than in the corresponding treatments in the N-response trial.

\section{Rotation trial: fallow and legume biomass production}

At both sites, the forage legume $S$. guianensis produced the highest mean biomass yield at the end of the rainy season compared to the other legumes and the natural fallow, varying between 12 and $18 \mathrm{Mg} \mathrm{ha}^{-1}$ in 1999-2003 (Fig. 2a, b). Part of the $S$. guianensis biomass, i.e. $6-14 \mathrm{Mg} \mathrm{ha}^{-1}$, was fed to cattle, while the remainder was left in the field. Cattle rejected the hard, lignified stems of $S$. guianensis harvested in 1999. Subsequently, only green plant parts were used as animal feed, resulting in a larger proportion of biomass being left in the field.
The fallow vegetation in Ibadan was dominated by Panicum maximum, mixed with Chromolaena odorata, Trichoplusia subcordata, Momordica charantia and other weeds. Biomass production of the fallow and $P$. phaseoloides vegetation at the end of the rainy season strongly varied from year to year in Ibadan (Fig. 2a). In 1999, the poor biomass production in both treatments could be related to poor rainfall conditions during establishment in 1998 (Fig 1a; Table 3). However, no relation between rainfall and biomass production could be established in other years. Field observations suggested a negative effect of leaf-eating beetles and grasshoppers on P. phaseoloides biomass production. The DP soybean crop in Ibadan suffered from several diseases, which increased in intensity over time and negatively affected foliage and grain production. In 2003, these included soybean rust (Phakopsora pachyrhizi), bacterial blight (Pseudomonas syringae pv. Glycinea) and soybean mosaic virus (Potyvirus spp.). Cowpea and grain soybean suffered less from diseases than DP soybean, possibly because of differences in planting time, growing period or crop variety. Consequently, the accumulated yield of the consecutive cultivations of cowpea and soybean in the grain legumes treatment was higher than that of the longduration soybean of the DP soybean treatment.

In Zaria, the fallow vegetation mostly contained Pennisetum pedicellatum and Indigofera spp. mixed with Piliostigma polystachion, Acacia nilotica and other weeds. Total biomass of the fallow vegetation was stable over the years, at 7-8 $\mathrm{Mg} \mathrm{ha}^{-1}$ (Fig 2b). Biomass production of A. histrix was highest in 2001, possibly as a result of favourable rainfall conditions during establishment (2000) and the main growing season (2001) (Fig. 1b; Table 3). Grain yield of DP soybean varied between 1.1 and $2.2 \mathrm{Mg} \mathrm{ha}^{-1}$, and foliage yields for cattle feed varied between 2.7 and $4.0 \mathrm{Mg} \mathrm{ha}^{-1}$. The combined aboveground biomass production in the intensive grain legumes treatment was approximately similar to that of DP soybean. Legume disease pressure in Zaria was low.

\section{Rotation trial: dry season production}

Over the 2003-2004 dry season, in Ibadan, the fallow vegetation produced large amounts of biomass, as shown by the difference in biomass in the field between the start and the end of the dry season 
Fig. 2 Biomass production (edible grain, foliage fed to cattle, and biomass remaining in the field) in fallow and legumes at the end of the rainy season in the rotation trial in Ibadan (a) and Zaria (b). Yields of the two consecutive grain legumes (cowpea and soybean) were accumulated
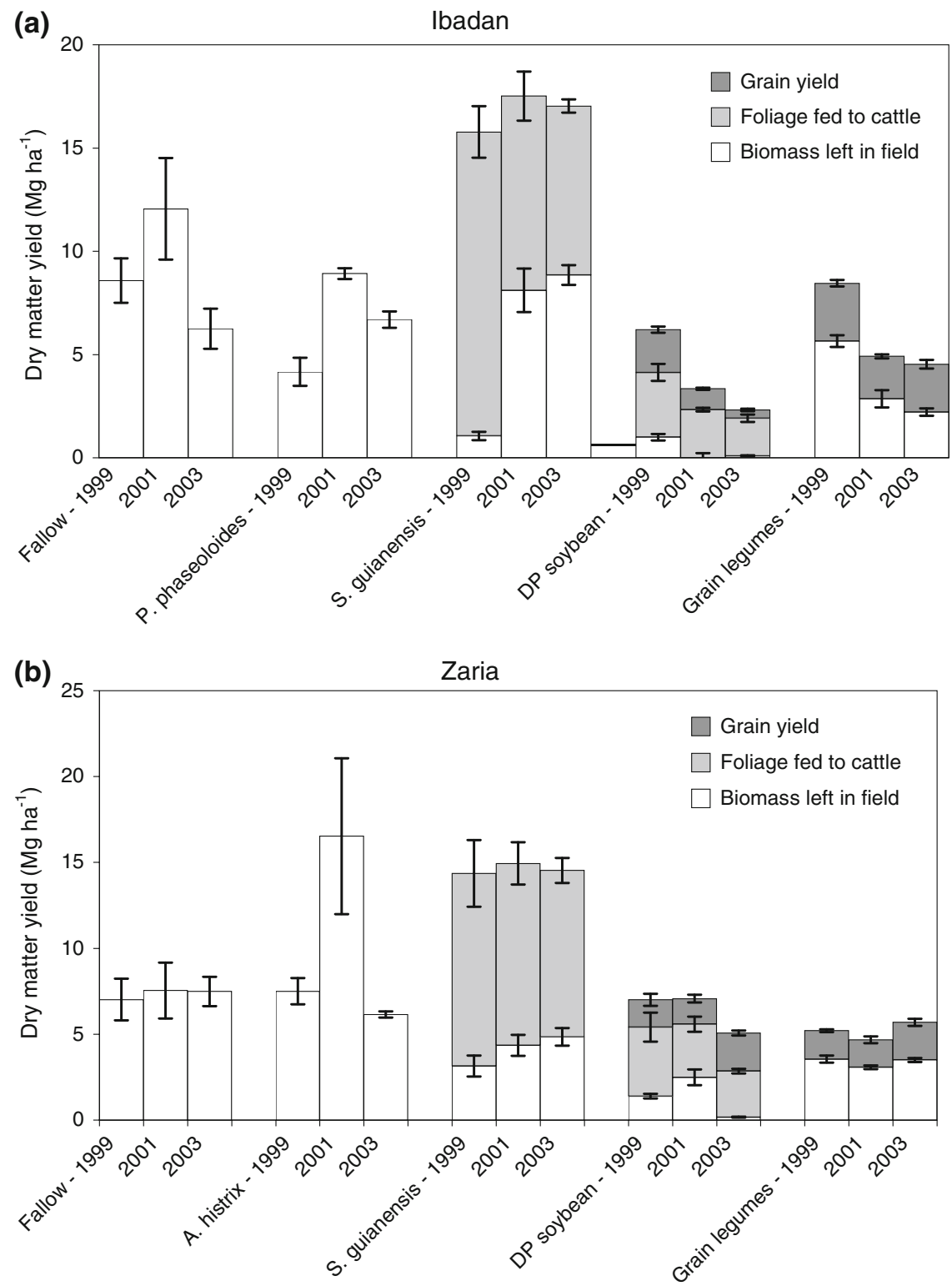

(Table 6). The biomass of the $P$. phaseoloides stand (green manure) was slightly reduced over the dry season. Moreover, the non-leguminous weed Panicum maximum competed with the crop and replaced some of the $P$. phaseoloides biomass. Residual biomass after harvest of DP soybean and grain soybean was small, but weeds produced some biomass over the dry season.

In Zaria, biomass in the fallow, A. histrix (green manure) and $S$. guianensis plots increased over the 2003-2004 dry season (Table 6). Aeschynomene histrix and $S$. guianensis are both drought-tolerant crops that can maintain growth well into the dry season. Residual biomass following DP soybean and grain legume cultivation at the end of the dry season was very low. Weeds grew little in Zaria after the harvest of edible legumes during the dry season and the soil remained mostly bare. Unlike the emerging weeds, the deep-rooted S. guianensis increased in biomass in Zaria over the dry season. Stylosanthes guianensis biomass did not increase during the dry season in Ibadan, which was probably related to the difference in the harvest method between the two locations. In Ibadan, all aboveground foliage was 
Table 6 Changes in aboveground biomass over the dry season in the rotation trial: biomass remaining in the field at the start of the dry season in 2003 (after harvest of edible grain and foliage for cattle feeding) and biomass in the field at the end of the dry season before land preparation for maize planting in $2004\left(\mathrm{Mg}\right.$ dry matter $\left.\mathrm{ha}^{-1}\right)$

\begin{tabular}{|c|c|c|c|c|}
\hline \multirow[t]{2}{*}{ Crop } & \multicolumn{2}{|l|}{ Ibadan } & \multicolumn{2}{|l|}{ Zaria } \\
\hline & $\begin{array}{l}\text { Biomass after } \\
\text { harvest } 2003\end{array}$ & $\begin{array}{l}\text { Biomass before land } \\
\text { preparation } 2004\end{array}$ & $\begin{array}{l}\text { Biomass after } \\
\text { harvest } 2003\end{array}$ & $\begin{array}{l}\text { Biomass before land } \\
\text { preparation } 2004\end{array}$ \\
\hline Fallow & 6.2 & $12.8^{\mathrm{a}}$ & 7.5 & $12.7^{\mathrm{a}}$ \\
\hline Green manure & 6.9 & 6.7 & 6.1 & 10.1 \\
\hline S. guianensis & 8.9 & 3.6 & 4.8 & 8.0 \\
\hline DP soybean & 0.1 & 3.4 & 0.2 & 0.3 \\
\hline Grain soybean & 1.0 & 4.1 & 2.2 & 0.4 \\
\hline
\end{tabular}

${ }^{a}$ Fallow vegetation was partially burned before maize planting

harvested, and the lignified parts, unpalatable for cattle, were separated from the green parts and returned to the field. These were partly lost over the dry season. In Zaria, only the green parts of $S$. guianensis were harvested, leaving the lignified stems intact. These continued to grow in the dry season.

\section{Rotation trial: $N$ and $P$ dynamics of legumes and fallow}

The accumulation of $\mathrm{N}$ and $\mathrm{P}$ in the aboveground biomass of S. guianensis at the 2003 harvest was large at both sites (Table 7). These nutrients were partly exported as cattle feed. The fallow and green manure vegetation remained in the field. In the DP soybean treatment in Zaria and the grain legume treatment at both sites, most of the nutrients were exported in grain (71-80\% of total $\mathrm{N}$ and $67-77 \%$ of total $\mathrm{P}$ in aboveground parts). The $\mathrm{N}$ and $\mathrm{P}$ in the foliage were either removed in cattle feed (DP soybean) or left in the field (grain legumes). Biomass production of DP soybean and the associated nutrient removal were low at the Ibadan site.

Changes in plant $\mathrm{N}$ and $\mathrm{P}$ content over the 20032004 dry season (Table 7) generally reflected the changes in aboveground biomass in that period (Table 6). At the start of the dry season in 2003, N content of the fallow vegetation was low at both sites but increased over the dry season at both sites, while $\mathrm{P}$ content increased only at the Ibadan site. Before land preparation in 2004, the natural fallow contained more $\mathrm{N}$ and $\mathrm{P}$ than the green manure and the other treatments. In Ibadan, the $\mathrm{N}$ and $\mathrm{P}$ content of $P$. phaseoloides and $S$. guianensis in the field at the beginning of the dry season was high but decreased over the dry season. Residual $\mathrm{N}$ and $\mathrm{P}$ in the field after harvest of DP soybean and grain legumes was low but increased in Ibadan over the dry season through the uptake by weeds. In Zaria, A. histrix $\mathrm{N}$ content at the start of the dry season was modest for a green manure crop, but it slightly increased over the dry season. Stylosanthes guianensis also accumulated $\mathrm{N}$ over the dry season in Zaria. The $\mathrm{P}$ content of A. histrix and S. guianensis grown in Zaria remained more or less stable over the dry season. Plant $\mathrm{N}$ and $\mathrm{P}$ remaining in the field after harvest of DP soybean and grain legumes disappeared almost entirely over the dry season in Zaria.

\section{Rotation trial: manure production and forage digestibility}

At both sites, large quantities of $S$. guianensis foliage fed to cattle led to high manure production (Table 8). Between 3.6 and $7.1 \mathrm{Mg} \mathrm{ha}^{-1}$ of manure dry matter, containing 60-130 kg N and 9-26 kg P, was applied to maize rotated with $S$. guianensis. Manure produced from the smaller quantity of DP soybean foliage, and the associated $\mathrm{N}$ and $\mathrm{P}$ content, were less: $1.2-1.8 \mathrm{Mg}$ dry matter $\mathrm{ha}^{-1}$, containing $17-29 \mathrm{~kg} \mathrm{~N}$ and $3-$ $5 \mathrm{~kg}$ P. The manure included faeces mixed with feed refusals and urine. The nutrient concentration in manure varied across treatments and sites between 1.15 and $2.13 \% \mathrm{~N}$ and 0.18 and $0.41 \% \mathrm{P}$. Mean recovery in the manure was $47 \%$ of the dry matter, $55 \%$ of the $\mathrm{N}$ and $90 \%$ of the $\mathrm{P}$ for the $S$. guianensis feed. Mean recovery in manure of the soybean residues fed to cattle were $55 \%$ of the dry matter, $61 \%$ of $\mathrm{N}$ and $116 \%$ of P. Nitrogen recoveries were high, but within the range found in other studies in Africa (Dada et al. 
Table 7 Aboveground fallow and legume $\mathrm{N}$ and $\mathrm{P}$ content at the 2003 harvest, $\mathrm{N}$ and $\mathrm{P}$ removed from the field during the harvest of edible grain and foliage $(\mathrm{N}$ and $\mathrm{P}$ of grain legumes combined), $\mathrm{N}$ and $\mathrm{P}$ remaining in the field after harvest and $\mathrm{N}$ and $\mathrm{P}$ content of biomass in the field before land preparation for maize planting 2004

\begin{tabular}{|c|c|c|c|c|c|c|}
\hline \multicolumn{7}{|c|}{ Nitrogen $\left(\mathrm{kg} \mathrm{N} \mathrm{ha}^{-1}\right)$} \\
\hline \multirow[t]{3}{*}{ Site } & \multirow[t]{3}{*}{ Crop } & \multicolumn{4}{|c|}{ Plant $\mathrm{N}$ at harvest 2003} & \multirow{3}{*}{$\begin{array}{l}\text { Plant N before } \\
\text { planting } 2004\end{array}$} \\
\hline & & \multirow[t]{2}{*}{ Total N } & \multicolumn{2}{|c|}{$\mathrm{N}$ removal } & \multirow{2}{*}{$\begin{array}{l}\mathrm{N} \text { remaining } \\
\text { in field }\end{array}$} & \\
\hline & & & Foliage & Grain & & \\
\hline \multirow[t]{5}{*}{ Ibadan } & Fallow & 30 & 0 & 0 & 30 & 159 \\
\hline & P. phaseoloides & 186 & 0 & 0 & 186 & 128 \\
\hline & S. guianensis & 290 & 134 & 0 & 156 & 58 \\
\hline & DP soybean & 51 & 24 & 25 & 2 & 50 \\
\hline & Grain legumes & 144 & 0 & 106 & 38 & 60 \\
\hline \multirow[t]{5}{*}{ Zaria } & Fallow & 35 & 0 & 0 & 35 & 111 \\
\hline & A. histrix & 80 & 0 & 0 & 80 & 95 \\
\hline & S. guianensis & 229 & 151 & 0 & 77 & 94 \\
\hline & DP soybean & 166 & 30 & 133 & 3 & 3 \\
\hline & Grain legumes & 156 & 0 & 110 & 46 & 5 \\
\hline \multicolumn{7}{|c|}{ Phosphorus $\left(\mathrm{kg} \mathrm{P} \mathrm{ha}^{-1}\right)$} \\
\hline \multirow[t]{3}{*}{ Site } & \multirow[t]{3}{*}{ Crop } & \multicolumn{4}{|c|}{ Plant P at harvest 2003} & \multirow{3}{*}{$\begin{array}{l}\text { Plant P before } \\
\text { planting } 2004\end{array}$} \\
\hline & & \multirow[t]{2}{*}{ Total P } & \multicolumn{2}{|c|}{$\mathrm{P}$ removal } & \multirow{2}{*}{$\begin{array}{l}\text { P remaining } \\
\text { in field }\end{array}$} & \\
\hline & & & Foliage & Grain & & \\
\hline \multirow[t]{5}{*}{ Ibadan } & Fallow & 12 & 0 & 0 & 12 & 19 \\
\hline & $\begin{array}{l}P . \\
\quad \text { phaseoloides }\end{array}$ & 18 & 0 & 0 & 18 & 13 \\
\hline & S. guianensis & 33 & 16 & 0 & 17 & 7 \\
\hline & DP soybean & 6 & 3 & 3 & 0 & 6 \\
\hline & Grain legumes & 16 & 0 & 11 & 5 & 7 \\
\hline \multirow[t]{5}{*}{ Zaria } & Fallow & 15 & 0 & 0 & 15 & 12 \\
\hline & A. histrix & 9 & 0 & 0 & 9 & 7 \\
\hline & S. guianensis & 21 & 14 & 0 & 7 & 7 \\
\hline & DP soybean & 13 & 3 & 10 & 0 & 0 \\
\hline & Grain legumes & 15 & 0 & 10 & 5 & 0 \\
\hline
\end{tabular}

1999; Rufino et al. 2006). These high recoveries may have been the result of careful forage and manure handling. Phosphorus recoveries were rather variable and sometimes above $100 \%$. It is possible that salt licks available to the cattle before the start of the feeding trial contained $\mathrm{P}$ that was excreted during the trial. Recoveries were higher in rotations with DP soybean than in those with $S$. guianensis, which was possibly associated with the loss of fragile $S$. guianensis leaves during transport and the preparation of foliage before feeding. An alternative explanation could be that cattle digested and metabolized $S$. guianensis foliage better than soybean foliage. This is, however, not supported by the higher content of lignin and of acid and neutral detergent fibre reported for $S$. guianensis compared to those for soybean foliage (Mani et al. 1994; Dada et al. 1999).

\section{Rotation trial: maize $N$ and $P$ concentration and uptake}

In 2004, the concentration of $\mathrm{N}$ in aboveground maize biomass was significantly affected by rotation only in Zaria (Table 9), while $\mathrm{N}$ uptake by maize was affected by rotation at both sites and by $\mathrm{N}$ rate in Ibadan. At both sites, $\mathrm{N}$ uptake was positively correlated to biomass production. In Ibadan, $\mathrm{N}$ uptake was relatively high after $S$. guianensis cultivation and 
Table 8 Dry matter (DM), $\mathrm{N}$ and $\mathrm{P}$ content of manure produced over the dry season and applied to maize in rotation with $S$. guianensis or DP soybean

\begin{tabular}{lllll}
\hline Site/crop & Dry season & $\mathrm{DM}\left(\mathrm{Mg} \mathrm{ha}^{-1}\right)$ & $\mathrm{N}\left(\mathrm{kg} \mathrm{ha}^{-1}\right)$ & $\mathrm{P}\left(\mathrm{kg} \mathrm{ha}^{-1}\right)$ \\
\hline Ibadan & & & 130 & 26 \\
S. guianensis & $1999-2000$ & 7.1 & 100 & 21 \\
& $2001-2002$ & 5.6 & 88 & 17 \\
& $2003-2004$ & 4.2 & 29 & 5 \\
Ibadan & & & 25 & 5 \\
DP soybean & $1999-2000$ & 1.6 & 17 & 4 \\
& $2001-2002$ & 1.5 & & 9 \\
Zaria & $2003-2004$ & 1.2 & 74 & 13 \\
S. guianensis & $1999-2000$ & 5.2 & 68 & 12 \\
& $2001-2002$ & 4.1 & 60 & 3 \\
Zaria & $2003-2004$ & 3.6 & 24 & 4 \\
DP soybean & $1999-2000$ & 1.8 & 21 & 5 \\
& $2001-2002$ & 1.5 & 18 & \\
\hline
\end{tabular}

Table 9 Nitrogen and phosphorus concentration and uptake in aboveground maize in the rotation trial at the 2004 harvest

\begin{tabular}{|c|c|c|c|c|c|c|c|c|}
\hline \multicolumn{9}{|l|}{ Nitrogen } \\
\hline \multirow[t]{3}{*}{ Rotation } & \multicolumn{4}{|c|}{ Ibadan } & \multicolumn{4}{|c|}{ Zaria } \\
\hline & \multicolumn{2}{|c|}{$\begin{array}{l}\text { N concentration } \\
\left(\mathrm{g} \mathrm{N} \mathrm{kg}^{-1} \text { dry matter }\right)\end{array}$} & \multicolumn{2}{|c|}{$\begin{array}{l}\mathrm{N} \text { uptake } \\
\left(\mathrm{kg} \mathrm{N} \mathrm{ha}^{-1}\right)\end{array}$} & \multicolumn{2}{|c|}{$\begin{array}{l}\mathrm{N} \text { concentration } \\
\left(\mathrm{g} \mathrm{N} \mathrm{kg}^{-1} \text { dry matter) }\right.\end{array}$} & \multicolumn{2}{|c|}{$\begin{array}{l}\mathrm{N} \text { uptake } \\
\left(\mathrm{kg} \mathrm{N} \mathrm{ha}^{-1}\right)\end{array}$} \\
\hline & $0 \mathrm{~N}$ & $60 \mathrm{~N}$ & $0 \mathrm{~N}$ & $60 \mathrm{~N}$ & $0 \mathrm{~N}$ & $60 \mathrm{~N}$ & $0 \mathrm{~N}$ & $60 \mathrm{~N}$ \\
\hline Fallow-maize & 7.8 & 7.6 & 45 & 62 & 5.0 & 6.2 & 21 & 50 \\
\hline Green manure-maize & 8.2 & 8.2 & 41 & 59 & 6.7 & 6.6 & 67 & 82 \\
\hline S. guianensis-maize & 9.1 & 8.4 & 69 & 84 & 7.7 & 6.5 & 94 & 78 \\
\hline DP soybean-maize & 7.4 & 7.7 & 28 & 47 & 7.3 & 7.2 & 81 & 80 \\
\hline Grain legumes-maize & 7.6 & 8.2 & 37 & 51 & 6.4 & 6.1 & 53 & 71 \\
\hline Standard error & 0.32 & 0.51 & 3.1 & 6.2 & 0.46 & 0.20 & 9.7 & 7.2 \\
\hline \multicolumn{9}{|l|}{ Phosphorus } \\
\hline \multirow[t]{3}{*}{ Rotation } & \multicolumn{4}{|c|}{ Ibadan } & \multicolumn{4}{|c|}{ Zaria } \\
\hline & \multicolumn{2}{|c|}{$\begin{array}{l}\text { P concentration } \\
\text { (g P kg-1 dry matter) }\end{array}$} & \multicolumn{2}{|c|}{$\begin{array}{l}\text { P uptake } \\
\left(\mathrm{kg} \mathrm{P} \mathrm{ha}^{-1}\right)\end{array}$} & \multicolumn{2}{|c|}{$\begin{array}{l}\text { P concentration } \\
\left.\text { (g P kg }{ }^{-1} \text { dry matter }\right)\end{array}$} & \multicolumn{2}{|c|}{$\begin{array}{l}\mathrm{P} \text { uptake } \\
\left(\mathrm{kg} \mathrm{P} \mathrm{ha}^{-1}\right)\end{array}$} \\
\hline & $0 \mathrm{~N}$ & $60 \mathrm{~N}$ & $0 \mathrm{~N}$ & $60 \mathrm{~N}$ & $0 \mathrm{~N}$ & $60 \mathrm{~N}$ & $0 \mathrm{~N}$ & $60 \mathrm{~N}$ \\
\hline Fallow-maize & 3.3 & 2.6 & 19 & 21 & 2.6 & 2.2 & 11 & 18 \\
\hline Green manure-maize & 2.1 & 2.3 & 11 & 16 & 2.1 & 1.7 & 21 & 21 \\
\hline S. guianensis-maize & 2.2 & 1.9 & 17 & 19 & 2.0 & 1.7 & 24 & 21 \\
\hline DP soybean-maize & 2.0 & 2.3 & 8 & 14 & 2.0 & 1.7 & 22 & 18 \\
\hline Grain legumes-maize & 2.3 & 2.2 & 11 & 13 & 1.6 & 1.5 & 13 & 17 \\
\hline Standard error & 0.27 & 0.24 & 1.7 & 1.9 & 0.18 & 0.15 & 1.9 & 1.1 \\
\hline
\end{tabular}


lower following the cultivation of DP soybean and grain legumes. As expected, urea-N applications resulted in a higher $\mathrm{N}$ uptake in Ibadan. In Zaria, $\mathrm{N}$ concentration and uptake in $0 \mathrm{~N}$ treatment was highest after $S$. guianensis, followed by the rotation with DP soybean; it was the lowest after fallow. In the $60 \mathrm{~N}$ treatment, differences in $\mathrm{N}$ concentration and uptake among the different legume-maize rotations were small.

Phosphorus concentration and uptake in 2004 were significantly affected by rotation at both sites (Table 9). Application of urea-N resulted in significantly higher P uptake only in Ibadan. In Ibadan, P concentration and uptake were increased after fallow. Differences in $\mathrm{P}$ concentration among rotations with legumes were small, while differences in $\mathrm{P}$ uptake primarily reflected variations in biomass accumulation. In Zaria, the $\mathrm{P}$ concentration was also higher following fallow, but $\mathrm{P}$ uptake was not, and it was lower in maize after fallow at $0 \mathrm{~N}$ than in the other treatments. Maize $\mathrm{P}$ concentration and uptake were lower in the grain legumes treatment than in the other rotations with legumes, especially at $0 \mathrm{~N}$. Differences in $\mathrm{P}$ concentration and uptake between DP soybean, A. Histrix and S. guianensis treatments were small in Zaria.

Table 10 Soil characteristics at planting in 2005 in the rotation trial (mean of subplots with and without $\mathrm{N}$ fertilizer); $\mathrm{pH}\left(\mathrm{H}_{2} \mathrm{O}\right)$ is presented for soil layers at depths of $0-12 \mathrm{~cm}$

\section{Rotation trial: soil characteristics}

At the start of the trial, the soil at a depth of $0-15 \mathrm{~cm}$ in Ibadan consisted of $80 \%$ sand, $9 \%$ silt and $11 \%$ clay and had a N-Kjeldahl concentration of $0.10 \%$, a soil organic $\mathrm{C}$ content of $7.0 \mathrm{~g} \mathrm{~kg}^{-1}$ and a Bray-I P content of $13.2 \mathrm{mg} \mathrm{kg}^{-1}$; it was therefore classified as moderately fertile. In Zaria, this layer consisted of $37 \%$ sand, $38 \%$ silt and $25 \%$ clay. The high clay and silt content made the soil surface prone to crusting. The soil had a N-Kjelldahl concentration of $0.06 \%$, an organic $\mathrm{C}$ content of $5.2 \mathrm{~g} \mathrm{~kg}^{-1}$ and a Bray-I P content of $3.4 \mathrm{mg} \mathrm{kg}^{-1}$; it was therefore classified as poorly fertile.

Before planting in 2005, the soil organic $\mathrm{C}$ and soil $\mathrm{C} / \mathrm{N}$ ratio were higher in the fallow-maize plots at both sites relative to the other rotations (Table 10). However, this increase was insignificant due to the high variability within rotations. Burning fallow vegetation before maize planting may have resulted in inert $\mathrm{C}$ formation in the soil, thereby enhancing the organic $\mathrm{C}$ and $\mathrm{C} / \mathrm{N}$ ratios. In Ibadan, $\mathrm{pH}$, Bray-I $\mathrm{P}$ and the exchangeable cations $\mathrm{K}, \mathrm{Ca}$ and $\mathrm{Mg}$ were all higher in the fallow-maize rotation than in the other rotations; the exchangeable $\mathrm{Ca}$ and $\mathrm{Mg}$ values were especially much greater. The Bray-I P content in the

and 12-24 cm, while other nutrient concentrations were converted to a soil mass basis, equivalent to a layer at a depth of $0.16 \mathrm{~m}$

\begin{tabular}{|c|c|c|c|c|c|c|c|c|c|}
\hline \multirow[t]{2}{*}{ Rotation } & \multirow{2}{*}{$\begin{array}{l}\text { pH (soil } \\
\text { depth: } \\
0-12 \mathrm{~cm})\end{array}$} & \multirow{2}{*}{$\begin{array}{l}\mathrm{pH} \text { (soil } \\
\text { depth: } \\
12-24 \mathrm{~cm} \text { ) }\end{array}$} & \multirow{2}{*}{$\begin{array}{l}\text { Organic C } \\
\left(\mathrm{Mg} \mathrm{ha}^{-1}\right)\end{array}$} & \multirow{2}{*}{$\begin{array}{l}\text { Kjeldahl N } \\
\left(\mathrm{Mg} \mathrm{ha}^{-1}\right)\end{array}$} & \multirow{2}{*}{$\begin{array}{l}\mathrm{C} / \mathrm{N} \\
\text { ratio }\end{array}$} & \multirow{2}{*}{$\begin{array}{l}\text { Bray-I P } \\
\left(\mathrm{kg} \mathrm{ha}^{-1}\right)\end{array}$} & \multicolumn{3}{|c|}{ Exchangeable cations $\left(\mathrm{kg} \mathrm{ha}^{-1}\right)$} \\
\hline & & & & & & & $\mathrm{K}$ & $\mathrm{Ca}$ & $\mathrm{Mg}$ \\
\hline \multicolumn{10}{|l|}{ Ibadan } \\
\hline Fallow-maize & 5.90 & 5.66 & 19.4 & 1.88 & 11.3 & 31.5 & 256 & 1,222 & 237 \\
\hline P. phaseoloides-maize & 5.73 & 5.65 & 18.2 & 1.95 & 9.5 & 26.3 & 168 & 963 & 133 \\
\hline S. guianensis-maize & 5.63 & 5.71 & 17.3 & 1.79 & 9.8 & 27.1 & 171 & 939 & 155 \\
\hline DP soybean-maize & 5.85 & 5.73 & 16.8 & 1.75 & 9.9 & 27.3 & 221 & 878 & 167 \\
\hline Grain legumes-maize & 5.83 & 5.76 & 17.1 & 1.62 & 10.9 & 17.8 & 228 & 949 & 153 \\
\hline Standard error & 0.076 & 0.106 & 1.70 & 0.265 & 1.12 & 4.51 & 24.8 & 151.4 & 19.2 \\
\hline \multicolumn{10}{|l|}{ Zaria } \\
\hline Fallow-maize & 5.61 & 5.65 & 18.0 & 1.37 & 13.2 & 18.1 & 282 & 1,816 & 344 \\
\hline A. histrix-maize & 5.55 & 5.44 & 15.4 & 1.28 & 12.1 & 12.2 & 258 & 1,615 & 355 \\
\hline S. guianensis-maize & 5.56 & 5.49 & 15.7 & 1.40 & 11.3 & 12.9 & 278 & 1,711 & 357 \\
\hline DP soybean-maize & 5.53 & 5.50 & 15.2 & 1.33 & 11.5 & 13.0 & 244 & 1,555 & 304 \\
\hline Grain legumes-maize & 5.64 & 5.63 & 14.4 & 1.25 & 11.6 & 11.6 & 278 & 1,797 & 336 \\
\hline Standard error & 0.154 & 0.141 & 1.53 & 0.074 & 1.18 & 2.12 & 14.9 & 121.8 & 22.9 \\
\hline
\end{tabular}


grain legume-maize rotation in Ibadan was lower than that in the other rotations. In Zaria, the Bray-I P content was significantly higher in the fallow-maize rotation than in the other rotations. Exchangeable $\mathrm{K}$ and $\mathrm{Ca}$ were significantly affected by rotation, with high levels in the fallow-maize rotation (though not significantly higher than that in most other rotations) and low levels in the DP soybean-maize rotation.

\section{Discussion}

In the N-response trial, in Ibadan, maize grain yield and the response to urea $\mathrm{N}$ applications declined in the course of the trial. In Zaria, higher $\mathrm{P}$ and $\mathrm{S}$ fertilizer rates in 2002 resulted in dramatically higher grain yields across $\mathrm{N}$ treatments, and the response to urea-N applications, and maize yields in 1998-2001 appeared primarily to be limited by $\mathrm{P}$ and/or $\mathrm{S}$ deficiencies. The poor soil $\mathrm{P}$ status in Zaria, a common feature of many savannah soils (Uyovbisere and Lombin 1991; Buerkert et al. 2001; Vanlauwe et al. 2002), was confirmed by the low soil Bray-I P at the start of the experiment. Sulphur deficiencies in cereals have also been reported in the savannah, especially in the drier, intensively farmed areas (Kang et al. 1981; Friesen 1991; Ojeniyi and Kayode 1993). In Zaria, over the period 2002-2004, mean grain yield declined in all $\mathrm{N}$ treatments, despite substantial $\mathrm{P}$ and $\mathrm{S}$ applications. Hence, fertilizer application at rates well above those generally applied by farmers (Bationo et al. 1998; Chianu and Tsujii 2004) appeared to be insufficient to sustain yield in continuous maize systems at both sites, which is in agreement with earlier observations (Jones 1971; Juo et al. 1995; Agbenin and Goladi 1997; Tian et al. 2005; Vanlauwe et al. 2005). Many factors may have contributed to this decline, such as a deterioration of the soil physical and chemical properties due to soil acidification, reduced soil organic matter content, soil compaction, increasing shortages of nutrients or rising biotic pressures.

In the rotation trial, the cultivation of certain legume types led to greater maize production relative to that found in the fallow-maize rotation and the corresponding treatments in the $\mathrm{N}$-response trial. However, other legume treatments produced no gain in maize yield. Large differences in residual effects from legumes and fallow were also observed between the derived savannah and the northern Guinea savannah, stressing the need for site-specific land management recommendations.

The cultivation of legumes and the fallow treatment affected the availability of $\mathrm{N}$ and $\mathrm{P}$ to maize, which are factors explaining at least part of the variation in maize yield between treatments. Changes in $\mathrm{N}$ and $\mathrm{P}$ availability were driven by factors such as $\mathrm{N}$ fixation by legumes, the export of $\mathrm{N}$ and $\mathrm{P}$ from the field during harvest, the carry-over of $\mathrm{N}$ and $\mathrm{P}$ over the dry season, nutrient losses during vegetation burning before planting, and the form in which $\mathrm{N}$ and $\mathrm{P}$ was present in the soil. Total legume $\mathrm{N}$ content at harvest (Table 7) may serve as an indicator for $\mathrm{N}$ fixation in the preceding period. The proportion of $\mathrm{N}$ derived from the atmosphere may be around $80 \%$ for green manure and forage legumes in the savannah (Sanginga et al. 1996a; Chikowo et al. 2006). In a sub-experiment of the rotation trial at both sites in 2005 in which the isotope dilution technique was used, we found that $80 \%$ of the $\mathrm{N}$ in DP soybean treatment was derived from the atmosphere (Laberge et al. in preparation). This is within the range for cowpea and soybean (between 25 and 80\%) reported by other studies (Okereke and Eaglesham 1993; Sanginga et al. 1997; Okogun et al. 2005; Chikowo et al. 2006). Furthermore, medium- and long-duration grain legumes derive a greater proportion of their $\mathrm{N}$ from the atmosphere than short-duration varieties (Sanginga et al. 1997; Singh et al. 2003).

Fallow vegetation produced well and accumulated $\mathrm{N}$ in the 2003-2004 dry season at both sites (Tables 6 and 7), as also observed by Muhr et al. (1999a) in the derived savannah. Although some legume species were found in the fallow vegetation, it is unlikely that fixation by legumes greatly contributed to this increase in $\mathrm{N}$ content. In Ibadan, soil characteristics in the upper layer of the fallow-maize rotation were improved relative to the other rotations in terms of Bray-I P and exchangeable $\mathrm{Ca}, \mathrm{Mg}$ and $\mathrm{K}$ (Table 10). It is possible that the natural fallow vegetation retrieved $\mathrm{N}, \mathrm{P}$ and cations from lower soil layers that were inaccessible to the more shallowly rooting legumes. No data on root architecture or soil properties below a soil depth of $0.24 \mathrm{~m}$ were collected to confirm this. Vanlauwe et al. (2005) found evidence of cation recycling by Senna siamea trees from lower soil layers and of an effect on soil properties in the top layer in a nearby agroforestry 
trial in Ibadan. While most of the aboveground $\mathrm{N}$ in the fallow vegetation of the current trial was probably lost when the fallow vegetation was partially burned, $\mathrm{P}$ and cations in the burned vegetation may have become readily available for plant uptake. The favourable soil properties in the fallow-maize rotation probably contributed to the high maize yield (Table 5) and the increased maize $\mathrm{P}$ concentration and uptake (Table 10) relative to the legume-maize rotations. In Zaria, $\mathrm{N}$ deficiencies probably limited the yield of maize after fallow, as indicated by the strong response to urea-N applications and the low maize $\mathrm{N}$ concentrations (Table 9). A high $\mathrm{N}$ uptake by the fallow vegetation and the subsequent loss of $\mathrm{N}$ during burning may have contributed to $\mathrm{N}$ shortages in this rotation. Phosphorus availability was unlikely to limit maize yield, as indicated by the high maize $\mathrm{P}$ concentration (Table 9) and soil Bray-I P content (Table 10). In contrast to the derived savannah of Ibadan, an 18-month fallow period in the northern Guinea savannah was inadequate for maintaining soil fertility and maize productivity.

Pueraria phaseoloides biomass production in Ibadan was high, and a high $\mathrm{N}$ content at harvest in 2003 suggested a good $\mathrm{N}$ fixation. However, maize yield in 2002-2004 and various soil properties (BrayI $\mathrm{P}$ and exchangeable $\mathrm{Ca}, \mathrm{Mg}$ and $\mathrm{K}$ ) at the end of the trial were more favourable in the fallow-maize rotation than in $P$. phaseoloides-maize rotation. The cultivation of a green manure crop requires investments in labour and seed, while the advantages of $P$. phaseoloides compared to the natural fallow were not evident. Hence, the use of $P$. phaseoloides - and green manure legumes in general- to improve soil fertility and cereal yields in the Guinea savannah should be recommended with caution. In contrast to our results, higher yields of cereals after green manure crops, in comparison with fallow-cereal rotations, have been reported in the derived savannah by others (Carsky et al. 2001; Tian et al. 2005), which may be explained by differences in yieldlimiting factors. Indigenous soil $\mathrm{N}$ supply in Ibadan was high, as indicated by the sustained maize yield in the non-fertilized treatment in the N-response trial. On severely $\mathrm{N}$ deficient soils, the $\mathrm{N}$-fixing abilities of $P$. phaseoloides may result in a higher maize yield than that obtained in the fallow-maize rotation. The ability of green manures to suppress weeds may also result in a cereal yield advantage, relative to a natural fallow, on lands severely infested by weeds. The production of the green manure A. histrix in Zaria was acceptable. Despite some A. histrix growth and N accumulation over the dry season (Tables 6 and 7), its $\mathrm{N}$ accumulation seemed to be modest for a green manure legume. The yield of maize after A. histrix cultivation was well above that after fallow, but the anticipated advantage of $A$. histrix as a green manure legume over other legume technologies in terms of improving soil fertility and maize yields was not obvious.

The biomass production and aboveground $\mathrm{N}$ content of $S$. guianensis were high, suggesting adequate $\mathrm{N}$ fixation at both sites. Despite $\mathrm{N}$ losses during cattle feeding, the residual effects of manure applications (Table 8) and S. guianensis plant residues (Table 7) were substantial, leading to high maize yields. Also, $\mathrm{N}$ concentration and $\mathrm{N}$ uptake of maize after $S$. guianensis cultivation were high, especially in Ibadan. Thus, S. guianensis showed a potential to provide animal feed and increase cereal yields in both agro-ecological zones. The importance of livestock production and the scarcity of suitable feed sources during the dry season in the northern Guinea savannah indicate a higher adoption potential of $S$. guianensis in this zone.

The performance of DP soybean in Ibadan was negatively affected by diseases in 2001 and 2003 . Susceptibility to diseases thus forms a major constraint for expanding long-duration soybean in the agro-environmental conditions of the derived savannah, unless more effective disease control strategies are developed or more resistant varieties are released. The other grain legumes suffered less from diseases and achieved a higher accumulated yield than DP soybean. In Zaria, both DP soybean and grain legumes produced acceptable grain yields. A high plant $\mathrm{N}$ content indicated the fixation of substantial amounts of atmospheric $\mathrm{N}$ by grain legumes at both sites and by DP soybean in Zaria. Substantial quantities of $\mathrm{N}$ and $\mathrm{P}$, and presumably other nutrients, were exported from the field in legume grains (Table 7), resulting in a net aboveground $\mathrm{N}$ accumulation close to zero or slightly negative in these legumes. This export of nutrients may have been responsible for the modest yield of maize after grain legumes that was observed in Ibadan in 2000-2004 and in Zaria in 2004 (Table 5), and also for the low soil Kjeldahl-N and Bray-I P values in Ibadan 
(Table 10) and the low maize $\mathrm{N}$ and $\mathrm{P}$ concentration and uptake in Zaria in the grain legumes treatment (Table 9).

In Zaria, the combined yield of the grain legumes and the partitioning of aboveground biomass, $\mathrm{N}$ and $\mathrm{P}$ over grain and foliage were similar to that of DP soybean (Fig 2b; Table 7), and the grain legume did not exhibit a higher harvest index. Virtually all aboveground residues and $\mathrm{N}$ and $\mathrm{P}$ remaining in the field after the harvest of DP soybean and grain legumes disappeared over the 2003-2004 dry season in Zaria (Tables 6 and 7). Although some biomass may have decomposed within the plot, most of the biomass and its associated nutrients were probably lost through wind and termite activity. When DP soybean foliage was used for cattle feeding, C, N and $\mathrm{P}$ were returned to the field in the form of manure at the subsequent maize planting (Table 8). The use of residues for animal feed and its associated manure production may thus be considered as a technology to preserve biomass and nutrients over the dry season that would be lost if left in the field, while at the same time yielding animal products for additional income. This is particularly important in areas such as the northern Guinea savannah where dry seasons last long and the grazing pressure by free-roaming animals is high. The yield of maize after the DP soybean rotation was higher than that of maize after the grain legumes rotation (Table 5), partly reflecting the greater recycling of nutrients in DP legumes. Ogoke et al. (2002) also noted that $C$ input to soil by soybean in cereal-based systems without livestock is minimal in the northern Guinea savannah.

In Zaria, the yield of maize after the DP soybean rotation was high compared to that in other rotations, especially at the beginning of the trial. It remains unclear why the mean yield of maize after the DP soybean rotation was, for example, higher than that of maize after the $S$. guianensis rotation, as the latter is a legume that achieved a far greater biomass and $\mathrm{N}$ accumulation than DP soybean. In the S. guianensis treatment, a high input of manure and plant material may have resulted in a temporary immobilization of soil N, while modest applications of manure and little post-harvest plant biomass production in plots of DP soybeans may have resulted in less $\mathrm{N}$ immobilization. Consequently, $\mathrm{N}$ release may have been more in synchrony with crop demand in the DP soybean treatment at the beginning of the trial, leading to higher yields. A large proportion of the DP soybean $\mathrm{N}$ was also found belowground in the roots and rhizodeposits, which was equivalent to more than $30 \mathrm{~kg} \mathrm{~N} \mathrm{ha}^{-1}$ (Laberge et al. in preparation). This belowground $\mathrm{N}$ may have been readily available to maize and could also be an explanatory mechanism for the high yield of maize following DP soybean.

The ranking of legume technologies and fallow in terms of their effectiveness for improving soil fertility and increasing cereal yield as stated in our hypothesis-green manure legume $>$ forage legume $>$ DP legume $>$ grain legume $>$ natural fallow-more or less reflects the order of plant $\mathrm{N}$ content of the legume and fallow vegetation remaining in the field at the start of the dry season (Table 7) plus the $\mathrm{N}$ applied as manure (Table 8). The impact of the rotations on maize production cannot be explained simply based on their aboveground $\mathrm{N}$ content. A greater understanding of the belowground $\mathrm{N}$ contribution of legumes and of soil $\mathrm{N}$ dynamics following residues and manure applications is needed to fully grasp the impact of these rotations on $\mathrm{N}$ availability to cereals. More effort should also be directed to determining the other factors that explain yield differences between rotations, in particular the dynamics of nutrients other than $\mathrm{N}$ and the other rotational effects of legumes, such as the impact on pest and diseases.

Acknowledgements The contributions of Messrs. Olelekan Tobe and Emmanuel Offor to the implementation of the trials are gratefully acknowledged. The authors also wish to thank the NAPRI and ILRI teams for their contributions to the cattle feeding and manure production, and the two anonymous peer reviewers for their useful comments on this paper.

Open Access This article is distributed under the terms of the Creative Commons Attribution Noncommercial License which permits any noncommercial use, distribution, and reproduction in any medium, provided the original author(s) and source are credited.

\section{References}

Agbenin JO, Goladi JT (1997) Carbon, nitrogen and phosphorus dynamics under continuous cultivation as influenced by farmyard manure and inorganic fertilizers in the savanna of northern Nigeria. Agric Ecosyst Environ 63:17-24

Alvey S, Bagayoko M, Neumann G, Buerkert A (2001) Cereal/ legume rotations affect chemical properties and biological activities in two West African soils. Plant Soil 231:45-54 
Alvey S, Yang C-H, Buerkert A, Crowley DE (2003) Cereal/ legume rotation effects on rhizosphere bacterial community structure in West African soils. Biol Fertil Soils 37:73-82

Bagayoko M, Buerkert A, Lung G, Bationo A, Römheld A (2000) Cereal/legume rotation effects on cereal growth in Sudano-Sahelian West Africa: soil mineral nitrogen, mycorrhizae and nematodes. Plant Soil 218:103-116

Bationo A, Lompo F, Koala S (1998) Research on nutrient flows and balances in West Africa: state-of-the-art. Agric Ecosyst Environ 71:19-35

Buerkert A, Bationo A, Piepho HP (2001) Efficient phosphorus application strategies for increased crop production in sub-Saharan West Africa. Field Crops Res 72:1-15

Buerkert A, Piepho HP, Bationo A (2002) Multi-site time-trend analysis of soil fertility management effects on crop production in sub-Saharan West Africa. Exp Agric 38: 163-183

Carsky RJ, Berner DK, Oyewole BD, Dashiell K, Schulz S1 (2000) Reduction of Striga hermonthica parasitism on maize using soybean rotation. Int $\mathrm{J}$ Pest Manage 46: $115-120$

Carsky RJ, Becker M, Hauser S (2001) Mucuna cover crop fallow systems: potential and limitations. Sustaining soil fertility in West Africa. SSSA Special Publ 58:111-135

Chianu JN, Tsujii H (2004) Determinants of farmers' decision to adopt or not adopt inorganic fertilizer in the savannas of northern Nigeria. Nutr Cycl Agroecosys 70:293-301

Chikowo R, Mapfumo P, Leffelaar PA, Giller KE (2006) Integrating legumes to improve $\mathrm{N}$ cycling on smallholder farms in sub-humid Zimbabwe: resource quality, biophysical and environmental limitations. Nutr Cycl Agroecosys 76:219-231

Dada SAO, Adeneye JA, Akinsoyinu AO, Smith JW, Dashiell KE (1999) Performance of sheep fed soybean stover and cassava crumb based diets. Small Rumin Res 31:229-238

De Ridder N, Breman H, Van Keulen H, Stomph TJ (2004) Revisiting a 'Cure against land hunger': soil fertility management and farming systems dynamics in the West African Sahel. Agric Syst 80:109-131

Ellert BH, Bettany JR (1995) Calculation of organic matter and nutrients stored in soils under contrasting management regimes. Can J Soil Sci 75:529-538

FAO (1988) FAO/UNESCO soil map of the world, revised legend. World Resources Report 60, FAO, Rome/Technical Paper 20, ISRIC, Wageningen 1989

Fofana B, Tamélokpo A, Wopereis MCS, Breman H, Mando A (2005) Nitrogen use efficiency by maize as affected by a mucuna short fallow and $\mathrm{P}$ application in the coastal savanna of West Africa. Nutr Cycl Agroecosys 71: $227-237$

Franke AC, Schulz S, Oyewole BD, Bako S (2004) Incorporating short-season legumes and green manure crops into maize-based systems in the moist Guinea savanna of West Africa. Exp Agric 40:463-479

Franke AC, Ellis-Jones J, Tarawali G, Schulz S, Hussaini MS, Kureh I, White R, Chikoye D, Douthwaite B, Oyewole BD, Olanrewaju AS (2006) Evaluating and scaling-up integrated Striga hermonthica control technologies among farmers in northern Nigeria. Crop Prot 25:868-878
Friesen DK (1991) Fate and efficiency of sulfur fertilizer applied to food crops in West Africa. Fert Res 29:35-44

Giller KE (2001) Nitrogen fixation in tropical cropping systems. CAB Int, Wallingford

IITA (1981) Analytical services laboratory manual. International Institute of Tropical Agriculture, Ibadan, Nigeria

Jones MJ (1971) The maintenance of soil organic matter under continuous cultivation at Samaru, Nigeria. J Agric Sci 77:473-482

Juo ASR, Franzluebbers K, Dabiri A, Ikhile B (1995) Changes in soil properties during long-term fallow and continuous cultivation after forest clearing in Nigeria. Agric Ecosyst Environ 56:9-18

Kang BT, Okoro E, Acquaye D, Osiname O (1981) Sulfur status of some Nigerian soils from the savanna and forest zones. Soil Sci 132:220-227

Litell RC, Milliken GA, Stroup WW, Wolfinger RD (1996) SAS system for mixed models. SAS Institute, Cary

Mani RI, von Kauffmann R, Egan AR, Dixon RM, Holmes JHG (1994) Development of grazing and utilisation strategies for stylo-based pasture supplies adapted to cattle production systems. In: de Leeuw PN, Mohamed-Saleem MA, Nyamu AM (eds) Stylosanthes as a forage and fallow crop. Proc Regional Workshop on the use of Stylosanthes in West Africa. ILCA, Addis Ababa, pp 155-165

Marschner P, Joergensen RG, Piepho H-P, Buerkert A (2004) Legume rotation effects on early growth and rhizosphere microbiology of sorghum in West African soils. Plant Soil 264:325-334

Mohamed Saleem MA, Otsyina RM (1986) Grain yields of maize and the nitrogen contribution following Stylosanthes pasture in the Nigerian subhumid zone. Exp Agric 22:207-214

Muhr L, Peters M, Tarawali SA, Schultze-Kraft R (1999a) Forage legumes for improved fallows in agropastoral systems of subhumid West Africa: II. Green manure production and decomposition after incorporation into the soil. Trop Grasslands 33:234-244

Muhr L, Peters M, Tarawali SA (1999b) Forage legumes for improved fallows in agropastoral systems of subhumid West Africa: III. nutrient import and export by forage legumes and their rotational effects on subsequent maize. Trop Grasslands 33:245-256

Muhr L, Tarawali SA, Peters M Schultze-Kraft R (2002) Soil mineral $\mathrm{N}$ dynamics and maize grain yields following Centrosema macroparcum and Stylosanthes guianensis: effects of different rotations and varying levels of $\mathrm{N}$ fertiliser. Field Crops Res 78:197-209

Murphy J, Riley JP (1962) A modified single solution method for the determination of phosphate in natural waters. Anal Chim Acta 27:31-36

Novozamsky I, Houba VJG, van Eck R, Van Vark W (1983) A novel digestion technique for multi-element plant analysis. Commun Soil Sci Plant Anal 14:239-248

Ogoke IJ, Carsky RJ, Togun AO, Dashiell K (2002) Organic carbon input by soyabean in the West African moist savanna. Biol Agric Hortic 20:133-142

Ojeniyi SO, Kayode GO (1993) Response of maize to copper and sulphur in tropical regions. J Agric Sci 120: 295-299 
Okereke GU, Eaglesham RJ (1993) Nodulation and nitrogen fixation by 79 "promiscuous" soybean genotypes in soil in east Africa. Agron Afr 2:123-136

Okogun JA, Sanginga N, Abaidoo R, Dashiell K, Diels J (2005) On-farm evaluation of biological nitrogen fixation potential and grain yield of Lablab and two soybean varieties in the northern Guinea savanna of Nigeria. Nutr Cycl Agroecosys 73:267-275

Rufino MC, Rowe EC, Delve JD, Giller KE (2006) Nitrogen cycling efficiencies through resource-poor African croplivestock systems. Agric Ecosyst Environ 112:261-282

Sanginga N (2003) Role of biological nitrogen fixation in legume based cropping systems; a case study of West Africa farming systems. Plant Soil 252:25-39

Sanginga N, Ibewiro B, Houngnandan P, Vanlauwe B, Okogun JA, Akobundu IO, Versteeg M (1996a) Evaluation of symbiotic properties and nitrogen contribution of mucuna to maize grown in the derived savanna of West Africa. Plant Soil 179:119-129

Sanginga N, Wirkom LE, Okogun A, Akobundu IO, Carsky RJ, Tian G (1996b) Nodulation and estimation of symbiotic nitrogen fixation by herbaceous and shrub legumes in Guinea savanna in Nigeria. Biol Fertil Soils 23:441-448

Sanginga N, Dashiell K, Okogun JA, Thottappilly G (1997) Nitrogen fixation and $\mathrm{N}$ contribution in promiscuous soybeans in southern Guinea savanna of Nigeria. Plant Soil 195:257-266

Sanginga N, Dashiell KE, Diels J, Vanlauwe ;B, Lyasse O, Carsky RJ, Tarawali S, Safo-Adjei B, Menkir A, Schulz S, Singh BB, Chikoye D, Keatinge D, Ortiz R (2003) Sustainable resource management coupled to resilient germplasm to provide new intensive cereal-grain-legumelivestock systems in the dry savanna. Agric Ecosyst Environ 100:305-314

SAS Institute (1999) SAS OnLINEDoc, ver. 8. SAS Institute, Cary

Schulz S, Carsky RJ, Tarawali S (2001) Herbaceous legumes: the panacea for West African soil fertility problems? Sustaining soil fertility in West Africa. SSSA Special Publ 58: 179-196

Schulz S, Diels J, Lyasse O (2002) Rehabilitation of severely degraded soil through the application of limiting nutrients: an example from Shika farm. In: IITA (ed) Improving and intensifying cereal-legume systems in the moist and dry savanna of West and Central Africa. Annual Report 2002. IITA, Ibadan, pp 4-5
Searle PL (1984) The Berthelot or indophenol reaction and its use in analytical chemistry of nitrogen. A review. Analyst (London) 109:549-568

Singh A, Carsky RJ, Lucas EO, Fernandez-Rivera S, Abubakar M (2003) Soil N balance as affected by soybean maturity class in the Guinea savanna of Nigeria. Agric Ecosyst Environ 100:231-240

Sumberg J (2002) The logic of fodder legumes in Africa. Food Policy 27:285-300

Swift MJ, Seward PD, Frost PGH, Qureshi JM, Muchena FN (1994) Long-term experiments in Africa: developing a database for sustainable land use under global change. In: Leigh RA, Johnston AE (Eds), Long-term experiments in agricultural and ecological sciences. CAB Int, Wallingford, pp 229-251

Tarawali SA (1994) The yield and persistence of selected forage legumes in subhumid and semi-arid west Africa. Trop Grasslands 28:80-89

Tarawali SA, Peters M (1996) The potential contribution of selected forage legume pastures to cereal production in crop-livestock farming systems. J Agric Sci (Cambridge) 127:175-182

Tarawali SA, Tarawali G, Larbi A, Hanson J (1995) Methods for the evaluation of forage legumes, grasses and fodder trees for use as livestock feed. ILRI Manual No 1. International Livestock Research Institute, Addis Ababa, Ethiopia

Thomas D, Sumberg JE (1995) A review of the evaluation and use of tropical forage legumes in sub-Saharan Africa. Agric Ecosyst Environ 54:151-163

Tian G, Kang BT, Kolawole GO, Idinoba GO, Salako FK (2005) Long-term effects of fallow systems and lengths on crop production and soil fertility maintenance in West Africa. Nutr Cycl Agroecosys 71:139-150

Uyovbisere EO, Lombin G (1991) Efficient fertilizer use for increased crop production: the sub-humid Nigeria experience. Fert Res 29:81-94

Vanlauwe B, Diels J, Aihou K, Iwuafor ENO, Sanginga N, Merckx R, Deckers J (2002) Fertility status of soils of the derived savanna and northern guinea savanna and response to major plant nutrients, as influenced by soil type and land use management. Nutr Cycl Agroecosys 62:139-150

Vanlauwe B, Diels J, Sanginga N, Merckx R (2005) Long-term integrated soil fertility management in South-western Nigeria: crop performance and impact on soil fertility status. Plant Soil 273:337-354 